MODERN RADIO ENGINEERING

AND TELECOMMUNICATION SYSTEMS

https://doi.org/10.32362/2500-316X-2019-7-4-44-53

(cc) BY

UDC 621.3.049.774

\title{
Nominal and Actual Values of Inductor and Capacitor Parameters at High Frequencies
}

\author{
Egor V. Gurov ${ }^{1, @, ~}$ \\ Saygid U. Uvaysov ${ }^{1}$, \\ Aida S. Uvaysova ${ }^{1}$, \\ Svetlana S. Uvaysova ${ }^{2}$
}

${ }^{1}$ MIREA - Russian Technological University, Moscow 119454, Russia

${ }^{2}$ National Research University «Higher School of Economics», Moscow 123592, Russia

${ }^{\circledR}$ Corresponding author e-mail: gurov.yegor@gmail.com

Coil inductance and capacitor capacitance depend on overall dimensions, structure, and ambient factors. They do not vary with frequency. Reactive component impedance is determined by inductance or capacitance respectively, if active resistance is not considered. This is true for the frequencies which are significantly lower than the self-resonant frequency of the component. Parasitic parameters contribution increases on approaching the self-resonant frequency. Therefore, the component's actual inductance and actual capacitance on operating frequency are defined. They are provided by manufacturers and differ from the nominal values. The actual values provide more accurate impedance of components near the considered frequency. Significant deviation from the considered frequency can cause impedance mismatch even more than the nominal values can provide. Frequency response of the high-frequency circuits such as analog filters and impedance match networks are determined by components impedance, not the nominal values. Thus, calculated values must be close to the actual values. The purpose of this article is to justify actual values application instead of nominal values.

Keywords: inductor, inductance, capacitor, MLCC, capacitance, impedance, reactance. 


\title{
Номинальные и эффективные значения параметров катушек индуктивности и конденсаторов \\ на высоких частотах
}

\author{
E.В. Гуров ${ }^{1, @,}$ \\ С.У. Увайсов ${ }^{1}$,

\section{А.С. Увайсова ${ }^{1}$,} \\ С.С. Увайсова ${ }^{2}$
}

${ }^{1}$ МИРЭА - Российский технологический университет, Москва 119454, Россия,

${ }^{2}$ Национальный исследовательский университет «Высшая школа экономики», Москва 123592, Россия

${ }^{\circledR}$ Aвтор для переписки, е-mail: gurov.yegor@gmail.com

Индуктивность катушек и емкость конденсаторов представляются физическими величинами, зависящими от геометрических размеров, конфигурации компонентов, параметров окружающей среды, причем эти величины не зависят от частоты протекающего через них переменного тока. Полное сопротивление реактивных компонентов, без учета активной составляющей, определяется их индуктивностью или емкостью, соответственно. Такое утверждение справедливо для частот, значительно более низких по сравнению c собственной резонансной частотой компонента, ближе к которой всё больший вклад вносят паразитные параметры. Поэтому вводятся понятия эффективной индуктивности и эффективной емкости, значения которых отличаются от номинальных и зависят от частоты. Данные величины предоставляются производителями компонентов. Эффективные индуктивность и емкость дают более точное значение полного сопротивления в окрестности рассматриваемой частоты. Если имеет место существенное отклонение частоты от рассматриваемой, ошибка может оказаться даже больше, чем при использовании номинальных значений. При проектировании высокочастотных цепей, таких, как аналоговые фильтры и согласующие цепи, частотную характеристику определяют импедансы компонентов, а не их номинальные значения. Таким образом, расчетные значения должны быть близки именно к эффективным номиналам. Целью данной статьи является обоснование случаев необходимости применения эффективных значений реактивных компонентов взамен номинальных.

Ключевые слова: катушка индуктивности, индуктивность, конденсатор, керамический конденсатор, емкость, полное сопротивление, реактивное сопротивление.

\section{Introduction}

$\mathrm{U}$ nlike resistors that dissipate energy, inductors and capacitors accumulate it. They are used in analog filters, matching circuits, delay circuits, and energy storage. The practically used inductance of coils in the high-frequency range (more than $10 \mathrm{MHz}$ ) usually lies below $1 \mu \mathrm{H}$, since the parasitic parameters significantly distort the characteristics with increasing frequency. For a similar reason, at high frequencies, ceramic multilayer capacitors with a capacity of up to $1 \mu \mathrm{F}$ are used. 
The characteristics of radio frequency filters and matching circuits are determined by the impedances of the used components. Real coils and capacitors have reactance as well as resistance, and the latter dissipates energy. It is not equal to the resistance at a constant current and depends on the frequency due to the influence of the skin effect and the proximity effect [1, 2]. Both inductors and capacitors have such a parasitic characteristic as the resonant frequency, that is, the coil has a capacitance, and the capacitor has an inductance [3-6].

For the analysis of electrical circuits at frequencies more than 10 times lower than the resonant frequency, a model with a Q-factor (or Q-model) is used, which is an indicator of active losses. Q-model consists of a series-connected ideal reactive component and resistance. At higher frequencies, the parasitic reactive component is introduced. Thus, the RLC model is obtained [6].

However, even the RLC-model may not provide sufficient accuracy for describing the real component. Manufacturers provide S-parameters (which are experimental results) as models closest to the real components, and also SPICE models based on them [7, 8].

The ideal coil inductance can be defined as the ratio of impedance to frequency. If we substitute the real measured resistance instead of the impedance, we obtain the so-called effective inductance, which depends on the frequency and is applied only at frequencies below the resonant frequency. Definitions of initial and effective inductance are also given in GOST 20718-75 ${ }^{1}$. Similarly, the concept of effective capacity can be introduced for a capacitor.

In addition to the above parasitic characteristics, MLCC has a capacitance dependence on voltage and temperature [9], the coil resistance depends on the current flowing through it. These parameters are not considered in this article. It is assumed that the components operate at a fixed temperature with low voltage and current signals.

When designing radio-frequency filters and matching circuits, it may be necessary to select the inductance coils and capacitors. SPICE models or S-parameters have the highest accuracy. However, the search process can be very difficult or impossible. The RLC model has good accuracy at frequencies close to the resonant ones. However, with variation of the nominal, the nominal value of the parasitic reactive component also has to be varied, which also causes additional difficulties. The Q-model does not provide acceptable accuracy at high frequencies. As a satisfactory solution, it is proposed to use a Q-model and effective nominal value (QAmodel), which can provide acceptable accuracy in a small arbitrary frequency range. That may be sufficient to solve a specific problem.

This article presents the dependence of the impedance on the frequency for the previously described inductors and capacitors models, a comparison with experimental values, for example, a specific coil and capacitor. Conclusions about the feasibility of using QA-models compared to other models of reactive components in the field of high frequencies are made.

\section{Inductors models}

\section{Ideal inductor}

The inductance of an ideal inductor depends only on its geometric dimensions, configuration, and magnetic properties of the surrounding space. Resistance is purely reactive and is determined

${ }^{1}$ GOST 20718-75. Interstate Standard. Inductance coils for telecommunication equipment. Terms and definitions. Moscow: Standartinform Publ., 2005. 54 p.

[ГОСТ 20718-75. Межгосударственный стандарт. Катушки индуктивности аппаратуры связи. Термины и определения. М.: Стандартинформ, 2005. 54 с.] 
by the formula:

$$
Z(\omega)=j \omega L=j 2 \pi f L
$$

where $j$ is complex unit; $\omega$ is circular frequency, $\mathrm{rad} / \mathrm{sec} ; f$ is frequency, $\mathrm{Hz} ; L$ is inductance, $\mathrm{H}$.

$Q$-model (model with a quality factor)

Q-model considers the active resistance of a real inductor. It describes well the behavior at low frequencies up to about $1 / 10$ of the resonant frequency (Fig. 1). The impedance is determined by the formula:

$$
Z(\omega)=R\left(\omega_{0}\right)+j \omega L
$$

where $R$ is Equivalent Series Resistor (ESR). The ESR is not equal to DC resistance and depends on frequency. In a Q-model the ESR is determined at a specific frequency $\omega_{0}$, which is selected depending on the frequency range under consideration.

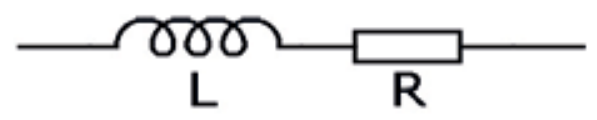

Fig. 1. Coil model with Q-factor.

The quality factor of the passive component is defined as the reactance to resistance ratio [10].

$$
Q(\omega)=\frac{\operatorname{Im}[Z(\omega)]}{\operatorname{Re}[Z(\omega)]}=\frac{\omega L}{R\left(\omega_{0}\right)}
$$

The quality factor is often indicated in the documentation for inductors and capacitors. Some simulators, for example, Keysight Genesys and Advanced Design System have a coil model with good quality in the standard library, where it is necessary to indicate its value at a specific frequency. In terms of quality, the total resistance can be determined by the formula:

$$
Z(\omega)=\omega L\left(\frac{1}{Q\left(\omega_{0}\right)}+j\right)
$$

\section{RLC model}

This model considers the influence of parasitic capacitance and has a resonant frequency (Fig. 2).

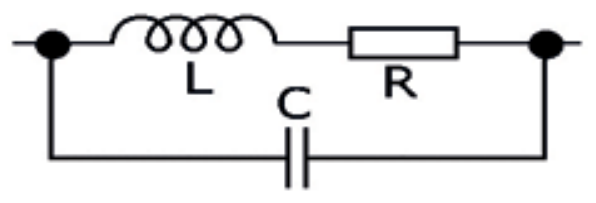

Fig. 2. RLC coil model.

Initially, the coil's own capacity was explained by inter-turn capacity [11]. However, the experimental results did not confirm this [12]. According to the results of more recent studies [13], it is proposed to abandon the static capacitance, considering the inductance coil as a long transmission line, and its own capacity depends on frequency [14]. 
Impedance is determined by the formula:

$$
Z(\omega)=\left(j \omega L+R\left(\omega_{0}\right)\right) \|\left(\frac{1}{j \omega C}\right)=\frac{R\left(\omega_{0}\right)+j \omega L}{1-\omega^{2} L C+j \omega C R\left(\omega_{0}\right)}
$$

Resistance $R$ and parasitic capacitance are frequency dependent. To simplify the calculations, we can take both parasitic values static. Active resistance can be chosen at the frequency of interest to us, as in a Q-model. The capacitance can be determined from the resonance frequency $\omega_{\text {res }}$ :

$$
\omega_{\text {res }}=\frac{1}{\sqrt{L C}} ; \Rightarrow C=\frac{1}{\omega_{r e s}^{2} L}
$$

\section{Q-model with effective inductance (QA-model)}

The impedance of an ideal inductance coil is determined by formula (1). Hence, as the dependence of the impedance on the frequency is known, we can determine the inductance:

$$
L=\frac{Z(\omega)}{j \omega}
$$

Substituting the experimental dependence instead of the ideal resistance $Z$, we obtain the so-called effective inductance, which depends on the frequency. It already includes the influence of parasitic capacitance.

QA-model is a model with a quality factor, in which the nominal component value is replaced by a constant value of the effective nominal at a specific frequency. Resistance is constant, determined at the same frequency.

$$
Z_{Q A}(\omega)=R\left(\omega_{0}\right)+j \omega L_{e f f}\left(\omega_{0}\right)
$$

\section{Capacitor models}

\section{Ideal capacitor}

In the case when the dielectric constant of the dielectric does not depend on the frequency, the capacitor capacitance is determined only by the geometric dimensions, the configuration of the capacitor, the properties of the dielectric and the surrounding space. Resistance is purely reactive and is determined by the formula:

$$
Z(\omega)=\frac{1}{j \omega C}
$$

where $C$ is capacitance, $\mathrm{F}$.

$Q$-model

Q-model considers the resistance of a real ceramic capacitor. It describes well the behavior at low frequencies up to about $1 / 10$ of the resonant frequency (Fig. 3). The impedance is determined by the formula:

$$
Z(\omega)=\frac{1}{j \omega C}+R\left(\omega_{0}\right)=\frac{1}{\omega C} \cdot\left(\frac{1}{Q\left(\omega_{0}\right)}-j\right)
$$




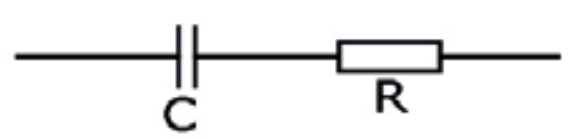

Fig. 3. RLC coil model.

\section{RLC model}

This model takes into account the influence of parasitic inductance, and it has a resonant frequency (Fig. 4).

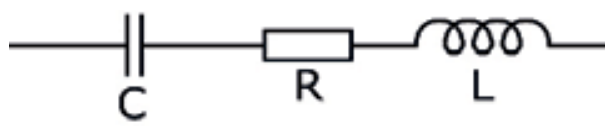

Fig. 4. RLC capacitance model.

The impedance is determined by the formula:

$$
Z(\omega)=R\left(\omega_{0}\right)+j \omega L+\frac{1}{j \omega C}
$$

The inductance of a capacitor is due to the inductance of the plates and outlets [15]. The resistance is due to the resistance of the plates and losses in the dielectric. Unlike inductors, these parasitic parameters are less dependent on frequency, and the RLC model describes the behavior of a capacitor more accurately than for an inductance coil.

\section{$Q$-model and effective inductance (QA-model)}

The impedance of an ideal capacitor is determined by the formula (9). As the dependence of the impedance on the frequency is known, we can determine the inductance:

$$
C=\frac{1}{j \omega Z}
$$

Substituting the experimental dependence instead of the ideal resistance $Z$ we obtain the so-called effective capacitance depending on frequency. It already includes the influence of parasitic inductance.

The QA model of the capacitor is similar to the QA model of the coil. Impedance is determined by the formula:

$$
Z_{Q A}(\omega)=R\left(\omega_{0}\right)+\frac{1}{j \omega C_{e f f}\left(\omega_{0}\right)}
$$

\section{Comparison between considered and experimental results}

The S-parameters or SPICE models can be used as experimental results. Murata provides for its products experimental frequency dependencies for impedance, active and reactive resistance, effective capacitance and inductance, quality factor and other parameters.

Consider an inductance coil for surface mounting $0603100 \mathrm{nH} \pm 5 \%$ LQG18HNR10J00 and a capacitor $0402 \mathrm{C} 0 \mathrm{G} 100 \mathrm{pF} \pm 5 \% 50 \mathrm{~V}$ GRM1555C1H101JA01. Let us estimate the deviations of the models considered earlier from the experimental characteristics provided by the manufacturer as an example of these two components.

The deviation from the experimental characteristics at a particular frequency is determined by the formula: 


$$
\delta=\frac{|e x-m|}{e x} \cdot 100 \%
$$

where ex is the experimental value; $m$ is the calculated value. The estimate of the simulation results deviation from the experimental values in the frequency range is determined by the formula:

$$
\sigma=\sqrt{\frac{\sum_{i=a}^{b}\left(e x_{i}-m_{i}\right)^{2}}{b-a}},
$$

where $a$ is the number of the lower frequency in the range, $b$ is the number of the upper frequency in the range. Here the deviation is given in absolute units.

\section{Inductor}

The dependence of the impedance on the frequency for different models of the inductor, as well as the experimental characteristic is shown in Fig. 5. The deviation of the calculated values from the experimental values is presented in Fig. 6.

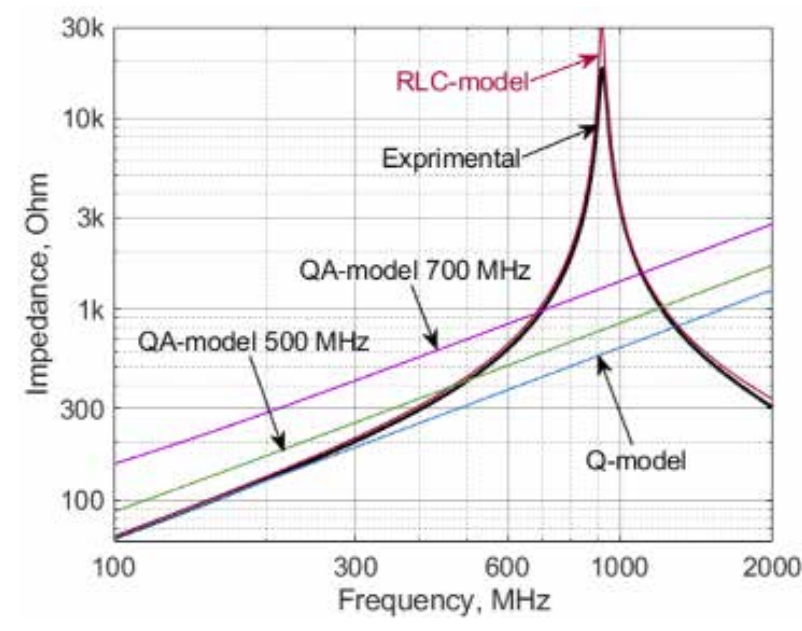

Fig. 5. Dependence of the impedance of the inductor models on the frequency.

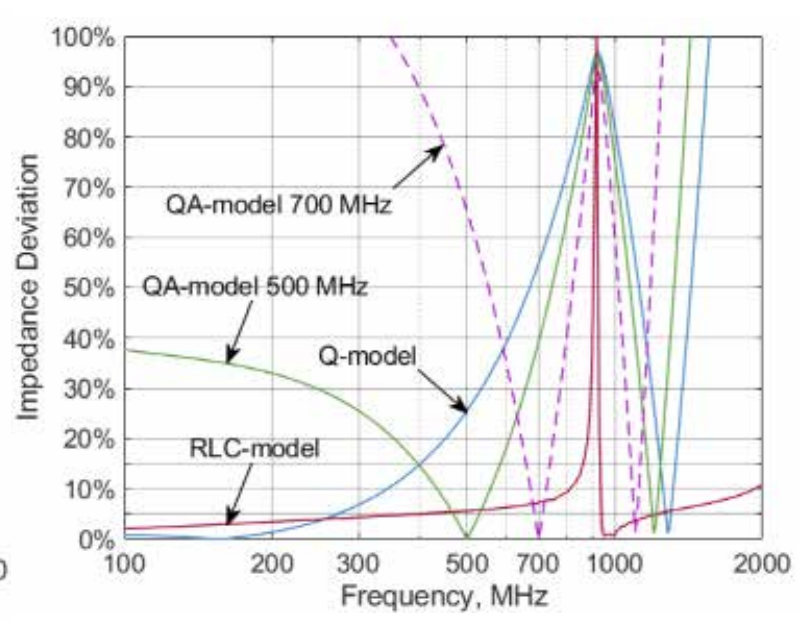

Fig. 6. Deviation of the calculated inductance impedance from experimental values.

Table 1 shows the impedances deviations of the inductance models under consideration from the experimental values in several frequency ranges. The second column «Capacitance» indicates the experimental coil resistance at the edges of the frequency range.

Table 1. Deviations of the impedance of various models of inductance from experimental values

\begin{tabular}{c|c|c|c|c|c}
\hline Range, MHz & $\begin{array}{c}\text { Capacitance, } \\
\text { Ohm }\end{array}$ & Q-model & RLC-model & $\begin{array}{c}\text { QA-model, } \\
500 \mathrm{MHz}\end{array}$ & $\begin{array}{c}\text { QA-model, } \\
700 \mathrm{MHz}\end{array}$ \\
\hline $30 \ldots 100$ & $20 \ldots 63$ & 0.8 & 1.1 & 19.0 & 78.8 \\
\hline $100 \ldots 300$ & $63 \ldots 202$ & 5.7 & 5.3 & 42.5 & 165.9 \\
\hline $300 \ldots 450$ & $202 \ldots 353$ & 42.1 & 14.1 & 46.6 & 261.4 \\
\hline $450 \ldots 550$ & $353 \ldots 508$ & 120.8 & 25.2 & 23.7 & 285.4 \\
\hline $650 \ldots 750$ & $765 \ldots 1303$ & 605.2 & 78.2 & 451.3 & 133.5 \\
\hline
\end{tabular}




\section{Capacitance}

The dependence of the impedance on the frequency for different models of the ceramic capacitor, as well as the experimental characteristic is shown in Fig. 7. The deviation of the calculated values from the experimental ones is presented in Fig. 8.

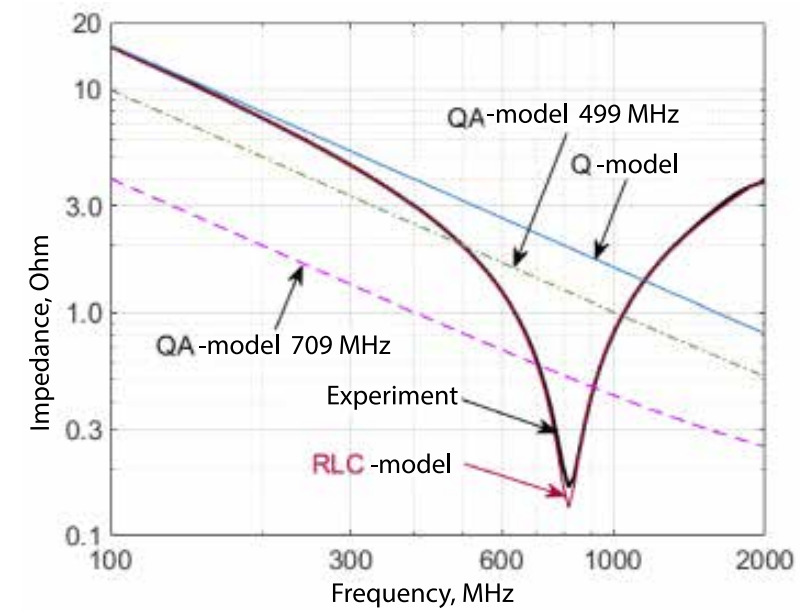

Fig. 7. Dependence of the impedance of ceramic capacitor models on the frequency.

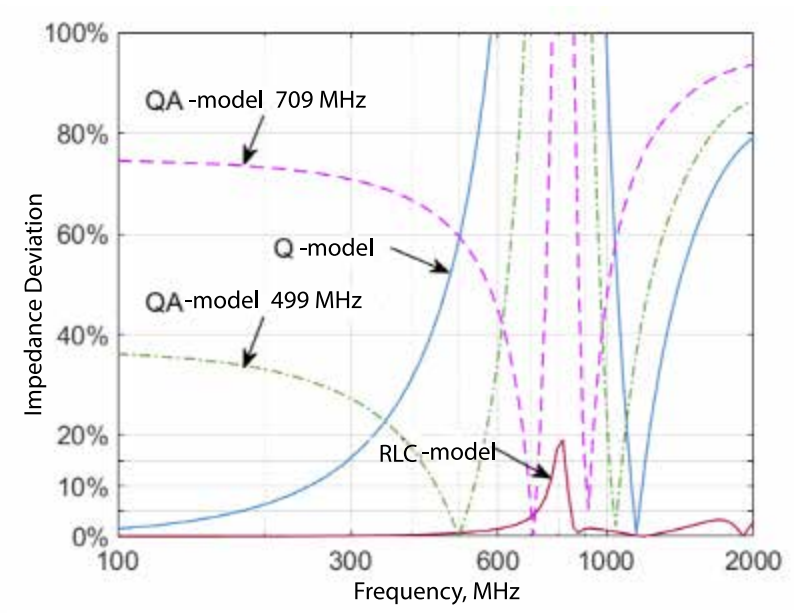

Fig. 8. Deviation of the calculated impedance of a ceramic capacitor from the experimental values.

Table 2 shows the deviations of the impedances of the considered models of a ceramic capacitor from the experimental values in several frequency ranges by analogy with Table 1 .

Table 2. Deviations of the impedance of various models of ceramic capacitor from the experimental values

\begin{tabular}{c|c|c|c|c|c}
\hline Range, $\mathrm{MHz}$ & $\begin{array}{c}\text { Capacitance, } \\
\text { Ohm }\end{array}$ & Q-model & RLC-model & $\begin{array}{c}\text { QA-model, } \\
500 \mathrm{MHz}\end{array}$ & $\begin{array}{c}\text { QA-model, } \\
700 \mathrm{MHz}\end{array}$ \\
\hline $100 \ldots 310$ & $15.68 \ldots 4.40$ & 0.54 & 0.005 & 3.24 & 6.94 \\
\hline $310 \ldots 457$ & $4.40 \ldots .40$ & 0.98 & 0.011 & 0.78 & 2.46 \\
\hline $457 \ldots 562$ & $2.40 \ldots 1.50$ & 1.33 & 0.016 & 0.19 & 1.27 \\
\hline $646 \ldots 751$ & $0.94 \ldots 0.37$ & 1.80 & 0.027 & 0.99 & 0.19 \\
\hline
\end{tabular}

\section{Conclusion}

In this article, three models of an inductance coil and a capacitor were considered: a Q-model, an RLC-model and a Q-model with effective value. The deviation error of the impedance was compared with the experimental data using the example of an inductor LQG18HNR10J00 and a capacitor GRM1555C1H101JA01.

For both components, the most accurate model considered at high frequencies to the resonant frequency was the RLC model. A Q-model at low frequencies for an inductor produces more accurate results due to the fact that the intrinsic capacitance is different at different frequencies [14], and for the RLC model it was determined at the resonant frequency.

A Q-model and an effective value can significantly reduce the error of a simple Q-model at frequencies above $1 / 10$ of the resonant frequency over a narrow frequency range. Moreover, the band where the error does not exceed an arbitrarily specified value (for example, 5\%) decreases as the frequency under consideration increases. The model is the most convenient in tasks where it is necessary to carry out the selection of component value, and high accuracy 
is needed in a narrow frequency band, for example, when designing radio frequency filters or matching circuits.

In order to practically apply the QA-model we need data on the dependence of the effective value on frequency, which are usually provided by the manufacturer. The required characteristics can be obtained from the S-parameters or the SPICE model. However, when it is necessary to select a specific type of component from a large set knowing only the required Q-factor and effective value, additional calculations lead to significant time costs. Therefore, when designing units of electronic high-frequency equipment where selection of nominal values is required, it is desirable to use components of those manufacturers that provide data on the effective values of nominals.

\section{References:}

1. Gatous O.M.O., Pissolato J. Frequency-dependent skin-effect formulation for resistance and internal inductance of a solid cylindrical conductor. In: IEE Proceed. Microwaves, Antennas and Propagation. 2004; 151(3):212-216. https://doi.org/10.1049/ip-map:20040469

2. Raven M.S. Experimental measurements of the skin effect and internal inductance at low frequencies. Acta Technica CSAV (Ceskoslovensk Akademie Ved.). 2015; 60:51-69.

3. Introduction to capacitor technologies. KEMET Electronics Corporation URL: http://www.kemet.com/ Lists/TechnicalArticles/Attachments/6/What\%20is\%20a\%20Capacitor.pdf. Accessed July 2, 2019.

4. Zumbahlen H. Basic Linear Design. Chapter 10: Passive components. Analog Devices, Inc., 2007. URL: https://www.analog.com/media/en/training-seminars/design-handbooks/Basic-Linear-Design/Chapter10.pdf. Accessed July 2, 2019.

5. Caio M., Pichorim S. Self-resonant frequencies of air-core single-layer solenoid coils calculated by a simple method. Electrical Engineering. 2014; 97(1):57-64. https://doi.org/10.1007/s00202-014-0312-3.

6. Green L. RF-inductor modeling for the 21 st century. EDN. September 2001. URL: https://m.eet.com/ media/1142818/19256-159688.pdf. Accessed July 2, 2019. $2,2019$.

7. S-parameters and SPICE models. Coilcraft. URL: https://www.coilcraft.com/models.cfm. Accessed July

8. S-parameter \& Equivalent Circuit Model. TDK. URL: https://product.tdk.com/info/en/technicalsupport/ tvcl/general/mlcc.html. Accessed July 2, 2019.

9. Prymak J., Randall M., Blais P., Long B. Why that $47 \mathrm{uF}$ capacitor drops to $37 \mathrm{uF}, 30 \mathrm{uF}$, or lower. Procced. CARTS USA 2008. 28 Symposium for Passive Electronics, March, Newport Beach, CA. URL: https:// www.researchgate.net/publication/229019152_Why_that_47_uF_capacitor_drops_to_37_uF_30_uF_or_lower. Accessed July 2, 2019.

10. Technical Terms RF Inductor. Murata Manufacturing Co., Ltd. URL: https://www.murata.com/en-eu/ products/inductor/chip/learn/glossary. Accessed July 2, 2019.

11. Skripnikov Yu.F. Oscillatory circuit. Moscow: Energiya Publ., 1970. 128 p., (in Russ.).

12. Medhurst R.G. (GEC Research Labs.) H. F. Resistance and Self-Capacitance of Single-Layer Solenoids. Wireless Engineer. February 1947. P. 35-43.

13. Knight D.W. The self-resonance and self-capacitance of solenoid coils: applicable theory, models and calculation methods (Technical report). May 2016. https://doi.org/10.13140/RG.2.1.1472.0887.

14. The self-capacitance of a single-layer air core solenoid (in Russ.). URL: https://coil32.net/theory/selfcapacitance.html. Accessed July 2, 2019.

15. Cain J. (AVX Corporation). Parasitic inductance of multylayer ceramic capacitors. February 2002 URL: https://www.avx.com/docs/techinfo/CeramicCapacitors/parasitc.pdf. Accessed July 2, 2019.

\section{Литература:}

1. Gatous O.M.O., Pissolato J. Frequency-dependent skin-effect formulation for resistance and internal inductance of a solid cylindrical conductor // In: IEE Proceed. - Microwaves, Antennas and Propagation. 2004. V. 151(3). P. 212-216. https://doi.org/10.1049/ip-map:20040469

2. Raven M.S. Experimental measurements of the skin effect and internal inductance at low frequencies // Acta Technica CSAV (Ceskoslovensk Akademie Ved). 2015. № 60. P. 51-69.

3. Introduction to capacitor technologies. KEMET Electronics Corporation [Электронный ресурc] - URL: http://www.kemet.com/Lists/TechnicalArticles/Attachments/6/What\%20is\%20a\%20Capacitor.pdf (дата обращения: 02.07.2019). 
4. Zumbahlen H. Basic Linear Design. Chapter 10: Passive components. Analog Devices, Inc., 2007 [Электронный ресурс] - URL: https://www.analog.com/media/en/training-seminars/design-handbooks/Basic-LinearDesign/Chapter10.pdf (дата обращения: 02.07.2019).

5. Caio M., Pichorim S. Self-resonant frequencies of air-core single-layer solenoid coils calculated by a simple method // Electrical Engineering. 2014. № 97. C. 57-64. https://doi.org/10.1007/s00202-014-0312-3.

6. Green L. RF-inductor modeling for the 21st century. EDN. September 2001 [Электронный ресурс] URL: https://m.eet.com/media/1142818/19256-159688.pdf (дата обращения: 02.07.2019).

7. S-parameters and SPICE models. Coilcraft [Электронный pecypc] - URL: https://www.coilcraft.com/ models.cfm (дата обращения: 02.07.2019).

8. S-parameter \& Equivalent Circuit Model. TDK [Электронный pecypc] - URL: https://product.tdk.com/ info/en/technicalsupport/tvcl/general/mlcc.html (дата обращения: 02.07.2019).

9. Prymak J., Randall M., Blais P., Long B. Why that $47 \mathrm{uF}$ capacitor drops to $37 \mathrm{uF}, 30 \mathrm{uF}$, or lower. Procced. CARTS USA 2008. 28 Symposium for Passive Electronics, March, Newport Beach, CA. URL: https://www. researchgate.net/publication/229019152_Why_that_47_uF_capacitor_drops_to_37_uF_30_uF_or_lower (дата обращения: 02.07.2019).

10. Technical Terms RF Inductor. Murata Manufacturing Co., Ltd. [Электронный pecypc] - URL: https:// www.murata.com/en-eu/products/inductor/chip/learn/glossary (дата обращения: 02.07.2019).

11. Скрипников Ю.Ф Колебательный контур. М.: Энергия, 1970. 128 с.

12. Medhurst R.G. (GEC Research Labs.) H. F. Resistance and Self-Capacitance of Single-Layer Solenoids. Wireless Engineer. February 1947. P. 35-43.

13. Knight D.W. The self-resonance and self-capacitance of solenoid coils: applicable theory, models and calculation methods (Technical report). May 2016. https://doi.org/10.13140/RG.2.1.1472.0887.

14. О собственной емкости однослойной катушки индуктивности. [Электронный pecypc] - coil32.ru. URL: http://coil32.ru/self-capacitance.html (дата обращения: 02.07.2019).

15. Cain J. (AVX Corporation). Parasitic inductance of multylayer ceramic capacitors. February 2002 [Electronic resource] - URL: https://www.avx.com/docs/techinfo/CeramicCapacitors/parasitc.pdf (дата обращения: 02.07.2019).

\section{About the authors:}

Egor V. Gurov, Postgraduate Student of the Chair of Design and Production of Radio Electronic Equipment, Institute of Radio Engineering and Telecommunication Systems, MIREA - Russian Technological University (78, Vernadskogo pr., Moscow 119454, Russia).

Saygid U. Uvaysov, Dr. of Sci. (Engineering), Head of the Chair of Design and Production of Radio Electronic Equipment, Institute of Radio Engineering and Telecommunication Systems, MIREA - Russian Technological University (78, Vernadskogo pr., Moscow 119454, Russia).

Aida S. Uvaysova, Postgraduate Student of the Chair of Design and Production of Radio Electronic Equipment, Institute of Radio Engineering and Telecommunication Systems, MIREA - Russian Technological University (78, Vernadskogo pr., Moscow 119454, Russia).

Svetlana S. Uvaysova, Postgraduate Student of the Department School of Computer Engineering, National Research University «Higher School of Economics» (34, Tallinskaya st., Moscow 123592, Russia).

\section{Об авторах:}

Гуров Егор Владимирович, аспирант кафедры конструирования и производства радиоэлектронных средств Института радиотехнических и телекоммуникационных систем ФГБОУ ВО «МИРЭА - Российский технологический университет» (119454, Россия, Москва, пр-т Вернадского, д. 78).

Увайсов Сайгид Увайсович, доктор технических наук, заведующий кафедрой конструирования и производства радиоэлектронных средств Института радиотехнических и телекоммуникационных систем ФГБОУ ВО «МИРЭА - Российский технологический университет» (119454, Россия, Москва, пр-т Вернадского, д. 78).

Увайсова Аида Сайгидовна, аспирант кафедры конструирования и производства радиоэлектронных средств Института радиотехнических и телекоммуникационных систем ФГБОУ ВО «МИРЭА - Российский технологический университет» (119454, Россия, Москва, пр-т Вернадского, д. 78).

Увайсова Светлана Сайгидовна, аспирант Департамента компьютерной инженерии Национального исследовательского университета «Высшая школа экономики» (123592, Россия, Москва, Таллинская ул., д.34).

For citation: Gurov E.V., Uvaysov S.U., Uvaysova A.S., Uvaysova S.S. Nominal and actual values of inductor and capacitor parameters at high frequencies. Rossiiskii tekhnologicheskii zhurnal = Russian Technological Journal. 2019; 7(4):44-53, (in Russ.). https://doi.org/10.32362/2500-316X-2019-7-4-44-53

Для цитирования: Гуров Е.В., Увайсов С.У., Увайсова А.С., Увайсова С.С. Номинальные и эффективные значения параметров катушек индуктивности и конденсаторов на высоких частотах // Российский технологический журнал. 2019. Т. 7. № 4. С. 44-53. https://doi.org/10.32362/2500-316X-2019-7-4-44-53 